\title{
ANÁLISE DE MÉTODOS PARA CRIAÇÃO DE INFOGRÁFICOS SOB O ENFOQUE DO DESIGN GRÁFICO E DA ERGONOMIA COGNITIVA
}

\section{ANALYSIS OF METHODS FOR CREATION OF INFOGRAPHICS UNDER THE GRAPHIC DESIGN AND COGNITIVE ERGONOMY APPROACH}

\author{
Marcos Bernardes ${ }^{1}$, Esp. \\ Flavio Anthero Nunes V. dos Santos ${ }^{2}$, D.Sc. \\ (1) PPG Design, UDESC \\ e-mail: oi@marcosbernardes.com \\ (2) PPG Design, UDESC \\ e-mail: flavioanvs@ hotmail.com
}

Palavras-chave: infográficos, métodos, ergonomia cognitiva

\begin{abstract}
O presente artigo é uma investigação exploratória acerca dos métodos de criação de infográficos a fim de identificar se aspectos da ergonomia cognitiva são levados em consideração durante o processo. A partir da análise do Manual de infografia da Folha de São Paulo e do resultado de entrevistas com especialistas foi possível compreender quais destes aspectos ergonômicos são considerados, além de observar as etapas de cada um dos métodos analisados.
\end{abstract}

Key-words: infographics, methods, cognitive ergonomics

The present paper is an exploratory investigation about the methods of infographic's creation in order to identify if aspects of cognitive ergonomics are taken into account during the process. From the analysis of the Manual of infographics of Folha de São Paulo and the result of interviews with specialists, it was possible to understand which of these ergonomics aspects are considered, besides observing the steps of each analyzed method.

\section{Introdução}

Diferentes correntes de estudo, sobretudo a partir do estruturalismo, sustentam a centralidade do sistema verbal entre as diferentes linguagens empregadas pelo ser humano. Contudo, não resta dúvida da importância das imagens nos processos cognitivos humanos. Kanno (2013) ilustra essa situação citando a palavra cadeira. Quando ela é falada, o que se forma na mente de quem ouve não são as sílabas que formam a palavra (ou registro gráfico), mas sim a imagem de uma cadeira (ou o referente). Sendo assim é compreensível que recursos de linguagem visual ou sincrética (aquelas que recrutam mais de um tipo de linguagem ao mesmo tempo, como a verbal, a visual, a sonora, etc) sejam utilizados com frequência em peças gráficas, como no exemplo da infografia.

A infografia é empregada no domínio do design gráfico e digital, havendo diferentes definições para o termo. Para Kanno (2013) a infografia é uma ferramenta que tem como objetivo comunicar combinando imagens e palavras. Por outro lado, 


\section{$16^{\circ}$ \\ ERGODESIGN USIHC CINAHPA}

$16^{\circ}$ Ergodesign - Congresso Internacional de Ergonomia e Usabilidade de Interfaces Humano Tecnológica: Produto, Informações Ambientes Construídos e Transporte

$16^{\circ}$ USIHC - Congresso Internacional de Ergonomia e Usabilidade de Interfaces Humano Computador

CINAHPA | 2017 - Congresso Internacional de Ambientes Hipermídia para Aprendizagem.
Cairo (2003) defende que a infografia não tem que ter necessariamente palavras, tomando como exemplo trabalhos importantes como o de Nigel Holmes, em Wordless Diagrams, de 2005.

Apesar de ser uma área comumente relacionada ao campo do design, a infografia é tratada frequentemente sob uma perspectiva jornalística. Isso se deve pela ampla aplicação deste recurso nas mídias jornalísticas, principalmente nas últimas décadas (MORAES, 2013).

Os estudos relacionados a infografia são recentes e grande parte deles enfocam na investigação de sua aplicação em jornais e revistas, portanto ainda há escassez de referências sobre a abordagem metodológica da criação deste recurso sob o enfoque do design gráfico e da ergonomia cognitiva. Tendo em vista esta lacuna, o presente artigo, sendo parte de uma investigação preliminar, possui objetivo exploratório de investigar a metodologia de criação de infográficos e identificar se aspectos da ergonomia cognitiva são levados em conta durante o processo. Para isso, foram analisados o Manual de Infografia da Folha de São Paulo, criado por Mario Kanno e Renato Brandão em 1998 e o resultado de entrevistas com especialista na área. Como contribuição secundária, buscou-se identificar se os métodos analisados têm pontos semelhantes entre si e se dialogam com as práticas profissionais empregadas pelos desenvolvedores de infográficos.

As entrevistas foram conduzidas pessoalmente ou através de contato via e-mail, utilizando um formulário estruturado que continha perguntas a respeito dos profissionais e dos métodos por eles empregados. Todos os entrevistados tem mais de cinco anos de experiência na área, sendo este o critério de escolha do corpus de pesquisa.

Com os resultados em mãos, os dados foram analisados a fim de identificar quais os aspectos da ergonomia cognitiva são levados em consideração durante o processo de criação tendo em vista os processos mentais cognitivos empregados na leitura de um infográfico.

Estes processos estão contemplados na ergonomia cognitiva e segundo a ABERGO são referentes a percepção, memória, raciocínio e resposta motora e o modo como estes processos afetam as interações entre os seres humanos e os outros elementos do sistema. Desta forma, os tópicos relevantes incluem os estudos de carga mental de trabalho, tomada de decisão, desempenho especializado, interação homem-computador, stress e treinamento, além de analisar como esses tópicos se relacionam a projetos envolvendo seres humanos e sistemas.

\section{Infografia}

\subsection{Conceitos e definições}

Há diversos conceitos de infografia, sendo que grande parte dos pesquisadores na área associam infografia diretamente a mídia jornalística. Parte disso, se dá pelo fato de que este meio de comunicação vem se utilizando da infografia como diferencial competitivo e estético, a fim de atrair novos leitores ou deixar seu conteúdo mais atrativo. Porém, outras áreas têm se beneficiado com este recurso, como a educação, o mercado editorial, os meios digitais, entre outros.

Para compreender melhor seu conceito, parte-se do próprio significado da palavra. Ribeiro (2008) cita que a expressão vem do termo inglês infographic, que por sua vez é uma redução de information graphics.

Moraes (2013) defende que a infografia pode ser entendida como um esforço de apresentar, de maneira clara, informações complexas demais para serem transmitidas apenas por textos. Cairo (2008), outro pesquisador da área, compreende infografia como uma representação diagramática de dados.

Teixeira (2010) acredita que infografia é entendida como uma modalidade discursiva na qual há presença indissociável de imagem e texto em uma construção narrativa que permite a compreensão de um fenômeno específico ou funcionamento de algo complexo. A autora ainda faz uma classificação dos infográficos, dividindo-os em duas categorias: os jornalísticos e os enciclopédicos. Os jornalísticos são relacionados àqueles que
Realização:

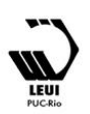




\section{$16^{\circ}$ \\ ERGODESIGN USIHC CINAHPA}

geralmente aparecem na imprensa (jornais e revistas) e narram fatos específicos ou noticiosos, já os enciclopédicos, são centrados em explicações de caráter mais universal como por exemplo, detalhes do funcionamento do corpo humano, o que são bactérias ou como se formam as nuvens.

Segundo Caixeta (2005), em seu artigo para o website da ABI - Associação Brasileira, a infografia é uma forma de representar informações técnicas como números, mecanismos e/ou estatísticas, que devem ser sobretudo atrativos e transmitidos ao leitor em pouco tempo e espaço. Normalmente utilizado em cadernos de saúde ou ciência e tecnologia, em que dados técnicos estão presentes, o infográfico vem atender a uma nova geração de leitores que é predominantemente visual e quer entender tudo de forma prática e rápida.

Schmitt (2006) define infografia como um sistema híbrido de comunicação, pois ao empregar imagens, palavras e números, utiliza um sistema de comunicação verbal (palavras e sentenças) e visual (imagens e representações gráficas).

Para Raymond Colle (2004) os campos de aplicação e estudo da infografia vão além da mídia jornalística e podem ser divididos em:

- Manuais de usuários, onde os infográficos inseridos nos manuais tem como objetivo auxiliar ou esclarecer as operações que o usuário irá desenvolver;

- Informes empresariais, que tratam das operações da empresa ou instituição;

- Infografia pedagógica, presente em manuais, livros e enciclopédias ligadas à educação;

- Infografia publicitária, presente na publicidade, como seu próprio nome sugere;

- Infografia técnica, baseada na simples associação e/ou integração de desenho e texto e encontrada em textos científicos ou manuais técnicos;

- Infografia jornalística, encontrada

frequentemente na mídia jornalística.

Sendo que os conceitos citados definem infografia, mas não o delimitam, ou seja, não os distinguem de outros recursos que utilizam linguagem $16^{\circ}$ Ergodesign - Congresso Internacional de Ergonomia e Usabilidade de Interfaces Humano Tecnológica: Produto, Informações Ambientes Construídos e Transporte

$16^{\circ}$ USIHC - Congresso Internacional de Ergonomia e Usabilidade de Interfaces Humano Computador

CINAHPA | 2017 - Congresso Internacional de Ambientes Hipermídia para Aprendizagem. sincrética, como mapa ou diagrama, este artigo usa como guia o conceito de Sancho (1999), que trata por infográfico um recurso gráfico composto por vários infogramas, que por sua vez são como unidades mínimas de informação gráfica, como um texto, um ícone, uma fotografia, um mapa ou uma ilustração.

Apesar dos conceitos serem variados, na questão do objetivo, pode-se entender que um infográfico tem como principais funções facilitar a comunicação, possibilitar que o leitor tenha a compreensão do texto ampliada, permitir uma visão geral dos acontecimentos e detalhar informações menos familiares ao público, desta forma, o conteúdo tem explicações em diversos níveis de complexidade, como apresentação de fatos ou acontecimentos, informações de funcionamento, descrição de procedimentos ou métodos.

\subsection{Um breve histórico}

Não é possível precisar quando surgiu o primeiro infográfico, porém, alguns pesquisadores e profissionais apontam para o que seriam as primeiras manifestações do que viria a ser chamado de infografia.

Os mais clássicos são os diagramas ilustrados de Leonardo da Vinci, que utilizavam linguagem sincrética e se aproximavam do que se conhece por infografia. Wildbur (1989) cita o economista Willian Playfair como um dos pioneiros no desenvolvimento e aplicação de representações gráficas para expressar dados estáticos. Seu livro, The Commercial and Political Atlas, publicado em 1786, trazia vários gráficos que buscavam elucidar dados da economia da Inglaterra neste período. Alguns dos diagramas criados por Playfair, como os dados de barras (figura 01), são utilizados até hoje e servem de base para o que é chamado de visualização de dados. 


\section{$16^{\circ}$ \\ ERGODESIGN USIHC CINAHPA}

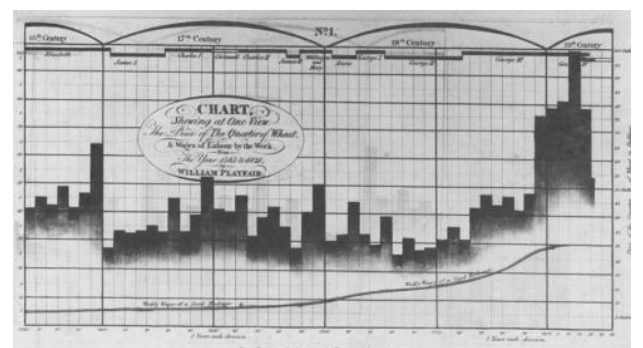

Figura 01: Diagrama de barras criado por Playfair Fonte: Moraes (2013), p. 25

Outros autores (TEIXEIRA, 2010; CAIRO, 2008; RIBEIRO, 2008; SANCHO, 2001) defendem que o primeiro infográfico tenha sido o intitulado " $\mathrm{Mr}$. Blight's House" (figura 02), veiculado no jornal londrino The Times, em abril de 1806, que detalhava a trajetória que o assassino Richard Patch percorreu, de seu esconderijo até o local onde matou sua vítima, Isaac Blight.

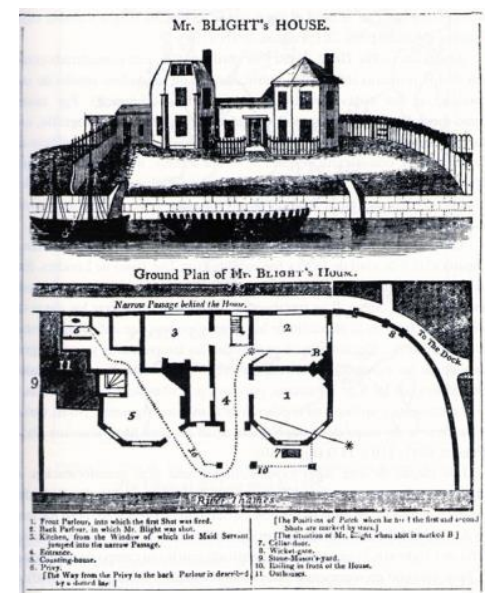

Figura 02: Mr. Blight's House Fonte: Teixeira (2010), p.17

Ainda neste sentido, Teixeira (2010) cita em seu livro o trabalho criado por John Snow, que produziu um mapa de Londres, cruzando informações que foram capazes de provar a ligação entre a água contaminada e a epidemia de cólera que assolava a cidade em meados de 1854 .

Moraes (2013) cita o diagrama criado por Charles Joseph Minard em 1812 que articula informações distintas em uma única peça gráfica. Nele, Minard se utiliza de uma quantidade mínima de textos, números, cores e representações gráficas para transmitir informações detalhadas sobre o desempenho do exército de Napoleão na campanha $16^{\circ}$ Ergodesign - Congresso Internacional de Ergonomia e Usabilidade de Interfaces Humano Tecnológica: Produto, Informações Ambientes Construídos e Transporte

$16^{\circ}$ USIHC - Congresso Internacional de Ergonomia e Usabilidade de Interfaces Humano Computador

CINAHPA | 2017 - Congresso Internacional de Ambientes Hipermídia para Aprendizagem.

da Rússia (1812-1813). Estas informações registram o espaço geográfico onde as tropas se deslocaram, o sentido deste deslocamento, as variações do tamanho do exército devido as baixas sofridas, e sensibilizavam o público a respeito da grande perda de vidas ocorrida no episódio em questão.

Já no século XX, o desenvolvimento de novas tecnologias introduzidas pela industrialização, a necessidade comunicacional derivada do crescimento urbano, a expansão da burguesia, o acesso à alfabetização e paralelamente, os movimentos de vanguarda artística intensificado na primeira metade do século contribuíram para o desenvolvimento de um novo vocábulo estético de formas e representações, e conseqüentemente, de um novo modo de se organizar as informações ou diagramas.

Para ilustrar estas mudanças, Moraes (2013) faz referência ao diagrama do sistema das linhas do metrô de Londres criado por Henry C. Beck (19011974) que simplificou o entendimento dos percursos do metrô se utilizando de linhas geométricas e rompendo assim com as formas geográficas londrinas utilizadas comumente em mapas. Outra referência é o sistema Isotype, desenvolvido pelo sociólogo austríaco Otto Neurath (1882-1945) e ilustrado por Gerd Arntz que se utilizava de imagens simples e icônicas, para comunicar informações que fossem compreendidas por letrados e iletrados.

No final da década de 80 os infográficos se popularizaram devido à revolução gráfica e principalmente ao lançamento do diário norteamericano USA Today em setembro de 1982. O jornal nasce então com uma proposta editorial caracterizada pelo uso de textos sintetizados, mapas, gráficos, formas inovadoras no uso de cores e desta forma, se diferenciava dos demais jornais. Segundo Moraes (2013) foi neste contexto dos anos 80 que surge a palavra infografia, como resultado da expansão do uso de gráficos informativos pelos jornais devido a concorrência entre os veículos.

Moraes (2013) também faz referência da história
Realização:
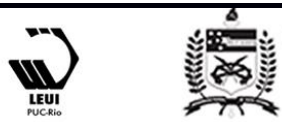


\section{$16^{\circ}$ \\ ERGODESIGN USIHC CINAHPA}

da mídia impressa no Brasil. Apesar dos mapas, gráficos estáticos, caricaturas e infográficos já fazerem parte do repertório de jornais nos anos de 1880, na década seguinte a utilização destes recursos foi abrangente, principalmente em jornais populares. Supostamente, este recurso ajudaria aqueles que não tinham a prática de leitura diária tão desenvolvida quanto os leitores de classes sociais com maior instrução e portanto, seguindo este raciocínio, os infográficos executavam a função de fazer a mediação entre a informação jornalística e o público.

Vale salientar que o avanço da tecnologia e a aplicação da infografia no ambiente web permitiram explorar novas características do recurso, como interatividade, convergência, hipertextualidade, customização de conteúdo e memória (Bardoel \& Deuze, 2000). Ainda neste sentido, quando o conteúdo da infográfica é alicerçado no cruzamento dinâmico de base de dados, este conteúdo pode ter atualização contínua e configurar em um meio diferente de visualização de informação, que por sua vez requer do usuário uma maior interação e atenção (Cairo, 2008).

Neste caso, para a compreensão do fenômeno, Tufte (2001) define visualização de dados como o procedimento de ajuda na análise e compreensão da informação de conjuntos complexos de dados em diferentes áreas do saber. Para Kumar e Garland (2006) a visualização de dados se faz importante para a apresentação e análise de gráficos com grande volume ou dados complexos.

\section{Métodos analisados}

A partir destas definições, e buscando compreender as etapas da criação, desde a apuração das informações, passando pelo processo criativo, produção final e avaliação do resultado final, esta pesquisa se divide entre a revisão bibliográfica do método encontrado no Manual de Infografia da Folha de São Paulo e no resultado das entrevistas.

\subsection{Método do manual da Folha de São Paulo}

O Manual de infografia da Folha de São Paulo foi produzido em um momento em que a infografia se $16^{\circ}$ Ergodesign - Congresso Internacional de Ergonomia e Usabilidade de Interfaces Humano Tecnológica: Produto, Informações Ambientes Construídos e Transporte

$16^{\circ}$ USIHC - Congresso Internacional de Ergonomia e Usabilidade de Interfaces Humano Computador

CINAHPA | 2017 - Congresso Internacional de Ambientes Hipermídia para Aprendizagem.

consolidava no Brasil e ao mesmo tempo gerava muitas dúvidas e apreensões. O material nasce então ao mesmo tempo que a necessidade de se esclarecer e aperfeiçoar o que se compreendia como linguagem infográfica (TEIXEIRA, 2010).

O livreto de trinta e seis páginas trata de aspectos práticos do recurso, como a categorização dos infográficos e dos elementos visuais que o compõem, além de detalhar aspectos relativos ao processo de produção visando uma melhor compreensão e padronização do processo. $\mathrm{O}$ manual ainda classifica infografia como um recurso gráfico que se utiliza de elementos visuais (elementos tipográficos, gráficos, mapas, ilustrações ou fotos) para explicar algum assunto ao leitor.

O processo de criação de infográfico registrado no manual se divide em três etapas, com alguns desdobramentos em cada uma delas:

1. Pauta. Inicialmente todo o assunto pode render um infográfico, porém, a questão é saber quando investir neste recurso. Neste momento algumas questões são levantadas a fim de fortalecer a decisão:

- A matéria é realmente importante?

- A edição tem espaço para o infográfico?

- Existe tempo hábil para a produção do mesmo?

2. Criação/edição. Checadas as primeiras questões, parte-se então para a escolha do tipo de infografia que será utilizado como tema central. Nesta parte do processo, que no caso da Folha ocorre dentro de uma edição do jornal, é importante que a equipe responsável pela arte defina junto como departamento de reportagem as primeiras providências a serem tomadas.

Novas questões servem de base para as seguintes definições:

- O que vai ser tratado como tema principal e o que vai ser dado como matéria de apoio no infográfico?

- Existe alguma imagem editorial que fortaleça a pauta? Caso haja um consenso sobres as questões acima relacionadas, o próximo passo é
Realização:

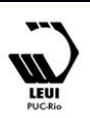




\section{$16^{\circ}$ \\ ERGODESIGN USIHC CINAHPA}

acionar o banco de dados e a reportagem para ter acesso à (s) imagem (ns), informação (ões) ou referência (as).

Verifica-se a existência da possibilidade ou da necessidade de mandar o infografista ao local, caso a imagem disponível não se encaixe no cenário decidido entre reportagem e equipe de arte.

3. Produção. Inicia-se a construção do infográfico para saber qual volume de texto será utilizado, checar se a ordem de leitura está clara e se é necessário acrescentar ou suprimir alguma informação.

A equipe de arte e reportagem então trabalham paralelamente na apuração, checagem e acabamento, até a montagem com os dados, textos e imagens finais.

Além disso, é importante observar que o manual destina uma página abordando aspectos da ergonomia cognitiva ao apontar itens que merecem a atenção do infografista para que o recurso se torne legível, compreensível e exerça sua função com eficácia. Abaixo seguem alguns dos itens relacionados:

- Fundos rebaixados e/ou confusos podem atrapalhar a leitura.

- Cores carnavalescas: o excesso de cores contrastantes pode distrair a ordem de leitura desejada.

- Destaques em excesso: podem confundir a ordem de leitura. A hierarquia deve ser dada apenas em destaques e estes devem ser no máximo dois, sendo que o restante do conteúdo deve ser colocado em segundo plano.

- Perspectivas inusitadas: a mídia impressa é acostumada a representar todas as figuras de lado, como os egípcios. Perspectivas criam um certo estranhamento e captam a atenção do leitor.

\subsection{Métodos empregados}

Tendo apresentado o material desenvolvido pela Folha de São Paulo para orientar o uso dos infográficos, o presente artigo analisa os diferentes $16^{\circ}$ Ergodesign - Congresso Internacional de Ergonomia e Usabilidade de Interfaces Humano Tecnológica: Produto, Informações Ambientes Construídos e Transporte

$16^{\circ}$ USIHC - Congresso Internacional de Ergonomia e Usabilidade de Interfaces Humano Computador

CINAHPA | 2017 - Congresso Internacional de Ambientes Hipermídia para Aprendizagem.

métodos empregados pelos infografistas entrevistados.

\subsubsection{Método do participante 01}

O processo de criação do participante 01 se divide em seis etapas:

1. Planejamento. Momento onde são discutidos definições como o tempo que será destinado para a tarefa, o espaço destinado ao infográfico no suporte escolhido (on-line, off-line), a distribuição de tarefas entre a equipe e as etapas do cronograma.

2. Investigação. Etapa na qual o infografista e todos os atores da equipe devem apurar a informação pesquisando fontes confiáveis, encontrando material de referência ou ir ao local do acontecido, caso o infográfico em questão seja relativo à um fato acontecido. Neste caso a verificação no local é feita para que haja um registro fotográfico a fim de conseguir todas as informações possíveis para compreender por completo o fato ou o acontecimento. Neste ponto o participante ressalta o cuidado especial com as fontes de informação da internet, que devem ser averiguadas antes de serem consideradas.

3. Criação. Nesta parte do projeto o infografista ou a equipe responsável pela criação começam a gerar esboços do desenho. Nenhuma ideia é descartada, já que segundo o participante, mesmo ideias que à primeira vista não são brilhantes podem ser caminhos para ideias melhores. O objetivo é privilegiar as informações visuais e evitar imagens meramente decorativas. O participante então utiliza perguntas que servem de base para a continuidade do projeto e a utilização da imagem proposta:

- A imagem escolhida acrescenta, reforça ou facilita a visualização do assunto principal? -A ideia faz o conteúdo da história mais relevante ou atraente?

- Há informação suficiente para sustentar essa ideia?
Realização:

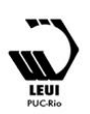




\section{$16^{\circ}$ \\ ERGODESIGN USIHC CINAHPA}

$16^{\circ}$ Ergodesign - Congresso Internacional de Ergonomia e Usabilidade de Interfaces Humano Tecnológica: Produto, Informações Ambientes Construídos e Transporte

$16^{\circ}$ USIHC - Congresso Internacional de Ergonomia e Usabilidade de Interfaces Humano Computador

CINAHPA | 2017 - Congresso Internacional de Ambientes Hipermídia para Aprendizagem.
4. O conteúdo. Nesta etapa o conteúdo deve ser analisado e se possível simplificado para manter o foco inicial do infográfico, eliminando assim dados em excesso que possam gerar ruído na comunicação. Ao mesmo tempo em que esta simplificação deve ser feita, é importante ter em mente que nenhuma informação importante pode ser retirada, pois isso pode prejudicar o entendimento do conteúdo. Com base nesta necessidade, novas perguntas são utilizadas para reforçar as decisões tomadas pelo infografista:

- Qual o objetivo dessa infografia?

- O que o leitor precisa saber está claro?

Se as dúvidas persistirem, como procedimento padrão, deve-se pedir para que uma terceira pessoa leia e opine sobre a clareza, a facilidade de leitura e a compreensão do conteúdo em questão.

5. Infográfico na página. Esta etapa consiste em delimitar as proporções da infografia e seus elementos, considerando a hierarquia visual que o recurso deve conter. Caso o infográfico seja disposto em uma página que contenha outros elementos, estes não devem competir entre si e sim se completar para contar a história proposta.

6. Edição e revisão. A etapa seis é destinada para refinamentos finais. Neste momento são checados se informações similares foram agrupadas em blocos com subtítulos, se foi gerado hierarquia da informação através de títulos e subtítulos, além da verificação e validação do conteúdo e de outros detalhes relevantes do projeto.

Quando o infográfico estiver pronto, deve-se enviar uma versão para uma terceira pessoa a fim conferir se está tudo certo. Esta revisão não deve ser deixada para última hora, pois a correção de informações textuais em um infográfico pode ser demorado, além de que em algumas situações, a alteração das informações textuais implica na alteração da ideia gráfica. A revisão deve priorizar textos verbais, deixando para segundo plano informações visuais como proporções ou ilustrações.

Durante a etapa da criação o infografista desenvolve as alternativas visando a compreensão e entendimento do conteúdo apresentado. Sendo assim, são levados em questão aspectos como:

- Leitura do texto. Neste quesito a preocupação é a respeito do tamanho e legibilidade da tipografia, visando uma leitura confortável.

- Leitura das imagens. O desenvolvimento ou a escolha de imagens que sejam compreendidas e auxiliem o texto verbal na transmissão do conteúdo.

\subsubsection{Método do participante 02}

O processo de criação do participante 02 se divide em três etapas com desdobramentos em cada uma delas:

1. Pauta. Período destinado para discussões de propostas da infografia. O conteúdo pode vir dos repórteres e editores, mas também pode ser sugerido pelo próprio infografista

Caso o conteúdo venha dos repórteres e/ou editores, as informações são analisadas a fim de confirmar se o mesmo requer a necessidade de ser explicado via infografia e se há recursos disponíveis: tempo, espaço no caderno ou informações suficientes.

Se o conteúdo for sugerido pelo próprio infografista, há uma ruptura na ordem do processo criativo comumente utilizado. Com o intuito de ter seu trabalho aprovado, o profissional em questão pesquisa algum tema que acredita ser interessante, desenvolve com base nestas pesquisas cerca de $60 \%$ do conteúdo informativo, estrutura a arte parcialmente e apresenta ao seu editor. Caso aprovado, os repórteres então são acionados para apurar as informações.

2. Criação/edição. Esta etapa se dá sempre após a aprovação do conteúdo na fase anterior, independente se o conteúdo foi trazido pelos repórteres ou pelo infografista com parte da arte já desenvolvida. 


\section{$16^{\circ}$ \\ ERGODESIGN USIHC CINAHPA}

Caso o conteúdo seja sugerido em pauta, iniciase um processo de estudos preliminares que parte do desenho central do infográfico, que demanda mais tempo e reitera aspectos relevantes no conteúdo. Após a figura central ser definida, começa-se a pensar na diagramação dos elementos textuais e como esses podem ser redistribuídos na layout de forma harmoniosa.

Se o conteúdo for sugerido pelo infografista, a tarefa de criação também se dá, porém parte-se de uma ideia já apresentada e aprovada, portanto neste caso o infografista trabalha nos detalhamentos e na diagramação dos elementos textuais.

3. Edição e revisão. Após a finalização da arte, o conteúdo é direcionado para um revisor de texto que verifica ortografia e gramática.

Caso esse conteúdo seja validado, o mesmo é passado para uma pessoa não vinculada a equipe desenvolvedora deste projeto em si, que novamente verifica o conteúdo a fim de confirmar se o conteúdo está compreensível e evitar possíveis distorções da informação. Se por fim estiver tudo aprovado o arquivo é encaminhado para a diagramação e posteriormente despachado para a impressão.

Se houver alguma correção, o conteúdo volta para o infografista que faz os ajustes necessários. O infográfico volta a ser revisado e se aprovado, então é finalizado e encaminhado para a diagramação (tendo em vista que o profissional em questão trabalha em um jornal), para finalmente o arquivo ser despachado para a impressão.

$\mathrm{Na}$ fase da criação, o infografista gera estudos pensando em questões estéticas e funcionais do recurso. Portanto, estas experimentações são feitas tendo em vista os aspectos da ergonomia cognitiva e pensando em como o leitor vai desempenhar a tarefa de ler e compreender a informação.

- Desenvolver meios ou pistas visuais para $16^{\circ}$ Ergodesign - Congresso Internacional de Ergonomia e Usabilidade de Interfaces Humano Tecnológica: Produto, Informações Ambientes Construídos e Transporte

$16^{\circ}$ USIHC - Congresso Internacional de Ergonomia e Usabilidade de Interfaces Humano Computador

CINAHPA | 2017 - Congresso Internacional de Ambientes Hipermídia para Aprendizagem. facilitar a leitura e a assimilação do conteúdo.

- Caso o infográfico tenha versão digital, desenvolve-se meios para que o leitor tenha maior interação, como botões ou áreas interativas, a fim de levar o leitor a ter uma experiência mais imersiva e interativa.

\subsubsection{Método do participante 03}

O processo de criação do participante 03 se divide em seis etapas:

1. Investigação. Etapa dedicada à pesquisa sobre o assunto em questão para que o mesmo seja melhor compreendido. Durante a pesquisa o infografista também recolhe imagens referenciais que servem de base para o desenvolvimento das imagens que construirão o recurso.

2. Arquitetura da informação. Procura-se um modelo de disposição da informação considerando os aspectos mais relevantes e criando assim uma hierarquia no conteúdo para que o infográfico seja legível e compreendido.

3. Revisão de conteúdo. Com a informação organizada, recorre-se ao jornalista responsável pelo conteúdo para que o mesmo faça a revisão e a validação.

4. Criação. Esta etapa se desdobra em:

- Wireframe. O desenvolvimento de uma estrutura básica, demonstrando de forma simples e direta a estrutura a ser desenvolvida, neste caso, delimitando os espaços dos títulos, informações textuais, imagens ou qualquer outro recurso gráfico do infográfico.

- Desenvolvimento da arte. Após a validação do wireframe, parte-se efetivamente para o desenvolvimento dos ícones, figuras e diagramação do conjunto de informações textuais e imagéticas.

5. Revisão. Após a finalização da arte, o conteúdo volta a ser direcionado para o jornalista responsável pelo conteúdo para que o mesmo valide o resultado obtido até esta etapa. 


\section{$16^{\circ}$ \\ ERGODESIGN USIHC CINAHPA}

$16^{\circ}$ Ergodesign - Congresso Internacional de Ergonomia e Usabilidade de Interfaces Humano Tecnológica: Produto, Informações Ambientes Construídos e Transporte

$16^{\circ}$ USIHC - Congresso Internacional de Ergonomia e Usabilidade de Interfaces Humano Computador

CINAHPA | 2017 - Congresso Internacional de Ambientes Hipermídia para Aprendizagem.
Caso o conteúdo seja validado, o mesmo segue para a arte final e posteriormente para a impressão.

Se houverem correções, o conteúdo volta para o infografista para que o mesmo faça os ajustes necessários, e quando estes forem validados após nova revisão, finalmente o arquivo é despachado para a arte final e posteriormente para a impressão.

\section{Arte final e impressão.}

O participante sempre que possível aplica as leis da Gestalt, considerando os padrões de comportamento visual, que são parte de um processo natural do cérebro durante a atividade de compreensão das formas visuais que nos dizem sobre o comportamento do olhar, da organização perceptiva e dos atalhos mentais que nosso cérebro cria para resolver as formas visuais.

Além das leis da Gestalt o infografista baseia-se na abordagem de Wucius Wong. Para ele, traços ou formatos podem ocorrer espontaneamente durante uma criação, porém, é possível criar reconhecendo previamente os problemas que precisam ser tratados. Em sua teoria, durante o processo de criação cada situação deve ser analisada, a fim esgotar de todas as opções gráficas disponíveis e escolha de elementos para dar funcionalidade a síntese e desta forma propor soluções visuais mais apropriadas e eficazes.

\subsubsection{Método do participante 04}

O processo de criação do participante 04 se divide em cinco etapas:

1. Análise de dados. Parte do processo destinado a pesquisa do conteúdo e busca de referências visuais para os elementos de composição do infográfico, que é feita em outros veículos como websites e livros;

2. Pré-diagramação. Como o próprio título sugere, nesta etapa o infografista começa o trabalho de dispor os elementos da composição a fim de compreender o espaço a ser trabalho e como será elegida a hierarquia de cada elemento.

3. Produção. Esta etapa engloba a geração de alternativas, criação de imagens ilustrativas ou fotográficas e refinamento do conjunto completo.

4. Inserção de textos. Mesmo que na etapa da prédiagramação o infografista já faça a utilização de textos, nem sempre estes são as versões finais, portanto esta fase é destinada à inserção dos textos finais e ajustá-los no layout.

5. Revisão. Após a finalização da arte, o texto passa primeiramente por uma revisão feita pelo próprio infografista e em seguida por outro responsável ou responsáveis, neste caso, o número de revisores dependerá da quantidade de pessoas envolvidas no projeto e do tempo disponível para o fechamento.

A fim de priorizar uma leitura eficaz, o infografista leva em consideração as leis da gestalt enquanto dispõe os elementos no conjunto. Assim como o participante anterior, a intenção é criar organização perceptiva e pistas visuais que os leitores já estejam acostumados para facilitar a leitura do conteúdo e indicar a ordem da mesma.

\section{Conclusão}

Conforme mencionado, grande parte da referência bibliográfica a respeito de processos metodológicos para criação de infográficos são voltados para a área da mídia jornalística e não se encontra uma abordagem única neste sentido. Assim a investigação contida neste artigo visa discutir a metodologia empregada na criação de infográficos sobre a ótica do design gráfico e da ergonomia cognitiva.

É possível constatar, através da amostra analisada, que tanto no método apresentado no Manual de infografia da Folha de São Paulo, quanto nos métodos dos entrevistados, algumas etapas, mesmo que tendo nomes diferentes, convergem em seu objetivo. Há etapas semelhantes em todos os métodos, assim como algumas variações ou desdobramentos, fazendo com que os processos se
Realização:

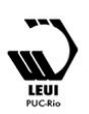




\section{$16^{\circ}$ \\ ERGODESIGN USIHC CINAHPA}

diferenciem entre referência bibliográfica e entrevistados e de um entrevistado para o outro.

A primeira etapa encontrada em três dos métodos analisados é a da pauta, que também é chamada de planejamento em um dos métodos, mas apesar de divergir na nomenclatura, tem em si o mesmo objetivo: gerar as primeiras definições do projeto, levantando questões a respeito dos recursos disponíveis de tempo e equipe, relevância do conteúdo e distribuição de tarefas.

O segundo ponto, comum entre todos os métodos analisados, é o da criação, que se trata da geração de alternativas para iconografia, criação ou edição de imagens, escolha de tipografia, imagens fotográficas e primeiros estudos da diagramação. Em alguns dos casos, este item vem logo após a pesquisa ou investigação e consiste na pesquisa e interação do assunto com o intuito de embasar a criação.

O terceiro item, comum em todos os métodos analisados se trata da revisão e apesar de estar presente em todos os métodos, é encontrado em posições diferentes nos distintos processos analisados. Nesta etapa ocorre a revisão ortográfica, a consistência dos textos e o resultado estético e funcional do conjunto.

A última etapa encontrada em todos os métodos é a da produção, que engloba a arte final, ou seja, os refinamentos e o fechamento do arquivo e o despacho para a diagramação ou para impressão. Apesar da produção se encontrar em todos os métodos investigados, em alguns momentos contem nomenclaturas diferenciadas ou desdobramentos dentro da etapa que diferem um método do outro.

Com as etapas analisadas é possível compreender que tanto no método do Manual de infografia da Folha de São Paulo, quanto nos métodos dos entrevistados o objetivo é compor um material que seja funcional, tendo em vista o próprio propósito do recurso. Sendo assim, foi identificado a preocupação com os aspectos cognitivos durante o processo de criação objetivando que a interação entre recurso e receptor seja eficiente. $16^{\circ}$ Ergodesign - Congresso Internacional de Ergonomia e Usabilidade de Interfaces Humano Tecnológica: Produto, Informações Ambientes Construídos e Transporte

$16^{\circ}$ USIHC - Congresso Internacional de Ergonomia e Usabilidade de Interfaces Humano Computador

CINAHPA | 2017 - Congresso Internacional de Ambientes Hipermídia para Aprendizagem.
Leitura e compreensão do texto são preocupações existentes em todos o métodos, assim como a escolha das imagens que reiterem o texto verbal ou ajudem a compor a leitura do conjunto contido no recurso. Também foi identificada a utilização de pistas visuais para orientar o receptor durante a tarefa da leitura e a preocupação em evitar a carga mental durante a leitura evitando o uso de recursos gráficos desnecessários ou meramente ilustrativos, fundos rebaixados que provocam um ruído visual ou o excesso de cores, imagens ou informações visuais que podem prejudicar a leitura. No caso do desdobramento do recurso para uma versão digital, além dos itens citados, se objetiva que o usuário tenha uma experiência interativa e uma leitura mais imersiva.

Como contribuição para trabalhos futuros sugerese um estudo mais aprofundado a respeito de métodos para criação de infográficos sob o enfoque do design gráfico e da ergonomia cognitiva. Além disso, é possível um estudo mais amplo a fim de identificar heurísticas que possam ser adaptadas ao recurso e posteriormente introduzidas em uma das etapas de sua criação. Sendo assim, é possível que um método englobe uma lista de verificações baseada nos processos cognitivos envolvidos na leitura e nas boas práticas do design com o intuito de criar infográficos eficientes na função da transmissão da informação.

\section{Referências bibliográficas}

CAIRO, Alberto. Infografia 2.0: visualización interactiva de información en prensa. Madrid: Alamut, 2008.

COLLE, Raimond. Estilos o tipos de infógrafos. Revista Latina de Comunicación Social. La Laguna (Tenerife), n. 12, dez, 1998. Disponível em:

<http://www.revistalatinacs.org/a/02mcolle/colle.ht $\mathrm{m}>$. Acesso em: 01 nov. 2016.

DE PABLOS, Jose Manuel. Infoperiodismo. EI Periodista como Creador de Infografia. Madrid: Editorial Sintesis, 1999.
Realização:

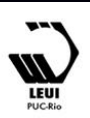




\section{$16^{\circ}$}

ERGODESIGN USIHC CINAHPA $16^{\circ}$ Ergodesign - Congresso Internacional de Ergonomia e Usabilidade de Interfaces Humano Tecnológica: Produto, Informações Ambientes Construídos e Transporte

$16^{\circ}$ USIHC - Congresso Internacional de Ergonomia e Usabilidade de Interfaces Humano Computador

CINAHPA | 2017 - Congresso Internacional de Ambientes Hipermídia para Aprendizagem.

KANNO, Mário. Infografe. Como e porque usar infográficos para criar visualizações e comunicar de forma imediata e eficiente. São Paulo: Infolide.com, 2013.

KUMAR, Gautam; GARLAND, Michael. Visual exploration of complex time - varying graphics. IEEE Transactions on Visualization and Computer Graphics, v. 12, n. 5.

MORAES, Ary. Infografia. História e Projeto Origens, conceitos e processos do design que modificou a forma da mídia mais tradicional da História. São Paulo: Blucher, 2013.

SANCHO, José Luis Valero. La Infografia: Técnicas, Análisis y Usos Periodísticos. Universitat Autònoma de Barcelona, Bellaterra, 2001.

SCHMITT, Valdenise. A Infografia Jornalística na Ciência e Tecnologia. Um experimento com estudantes de jornalismo da Universidade Federal de Santa Catarina. Dissertação (Engenharia e Gestão do Conhecimento). Florianópolis: UFSC - Universidade Federal de Santa Catarina, 2006.

TEIXEIRA, Tattiana. Infografia e Jornalismo: conceitos, análise e perspectivas. Salvador: EDUFBA, 2010.

TUFTE, Edward. The visual display of quantitative information. Connecticut: Graphic Press, 2001.

\section{Agradecimentos}

Ao programa de pós-graduação em design da UDESC, aos professores que fazem parte do corpo docente, especialmente aos professores Flavio Anthero Nunes Viana dos Santos e Murilo Scoz. 